\title{
Molecular and biochemical responses of horticultural plants and crops to heat stress
}

\author{
Seyedeh Somayyeh Shafiei Masouleh ${ }^{1^{*}}$, Youssef Najib Sassine ${ }^{2}$
}

\begin{abstract}
Various abiotic stresses affect growth and development of plants and one of them that causes severely decreasing the horticultural and crop yields is the heat stress worldwide. In this paper, the effects of heat (more than $30-35{ }^{\circ} \mathrm{C}$ in different species) stress on the horticultural plants and crops, and its effects on inducing other stresses, including osmotic and oxidative stresses are discussed. Plants show the molecular and biochemical responses after receiving environmental signals such as high temperatures and tolerate undesirable conditions.
\end{abstract}

Keywords: Abiotic stresses, abscisic acid, gene activation, high temperature.

\section{Resumo}

Respostas bioquímicas e moleculares ao estresse por calor em culturas e plantas hortícolas

Vários estresses abióticos afetam o crescimento e desenvolvimento de plantas, sendo um deles responsável por severas perdas na produção de culturas e hortícolas no mundo, o estresse por calor. Nesse artigo, o efeito do estresse por calor (superior a $30-35{ }^{\circ} \mathrm{C}$ para diferentes espécies) em culturas e plantas hortícolas e seu efeito na indução de outros estresses, incluindo estresse osmótico e oxidativo são discutidos. As plantas demonstram respostas bioquímicas e moleculares após receberem sinais ambientais como altas temperaturas e toleram condições indesejáveis.

Palavras-chave: estresse abiótico, ácido abscísico, ativação gênica, alta temperatura.

\section{Introduction}

Environmental stresses threaten the life of plants in the earth. One of these cues is heat stress because of global warming that intensifies other problems, including water deficiencies and salinity. Therefore, due to increasing population growth in the world, food supply and creating a place of relaxation for human, the agricultural biotechnologies and plant breeding to overcome abiotic stresses are necessary (Vinocur and Altman, 2005). Plants are mostly exposed to the physiological and biochemical damages at higher or lower temperatures than optimum. These injuries affect the metabolic processes, and decrease growth rates of plants and finally cause lower economic yield. About heat stress can be said that it causes producing the phenolic compounds, including flavonoids and phenylpropanoids in plants. These compounds lead to damages. Temperature is the most important factor for plants because the changes of ambient temperatures occur faster compared to other stress agents (Shafiei Masouleh et al., 2019). Plants adapt to abiotic stresses through cascades of molecular networks. These activate some mechanisms for re-establishing homeostasis and protecting and repairing the injured membranes and proteins. Genetically, complex responses to abiotic stresses are multigenic, therefore more difficult to control and engineer than biotic stresses, which are monogenic traits (Vinocur and Altman, 2005).

Plant biotechnology strategies to create tolerance to abiotic stresses depend on the expression of genes in signaling and regulatory pathways or genes encoding proteins or enzymes present in pathways of synthesis of functional and structural metabolites. Several achievements have been observed through biotechnology; however, abiotic stress tolerance includes genetically complex mechanisms. Therefore, genetic engineering should be completely integrated with classical physiology and

\footnotetext{
${ }^{1}$ Agricultural Research, Education and Extension Organization (AREEO), Horticultural Sciences Research Institute (HSRI), Ornamental Plants Research Center (OPRC), Department of Genetics and Breeding, Mahallat, Iran.

*Corresponding author: shafiee.masouleh@areeo.ac.ir; shafyii@gmail.com

${ }^{2}$ Lebanese University, Faculty of Agricultural Engineering and Veterinary Sciences, Department of Plant Production, Beirut, Lebanon
}

Received Jan 01, 2020 | Accepted Apr 04, 2020| Available online Apr 15, 2020

Licensed by CC BY 4.0

https://doi.org/10.1590/2447-536X.v26i2.2134

Area Editor: Márkilla Zunete Beckmann-Cavalcante 
breeding (Vinocur and Altman, 2005). This needs to know about the physiology of tolerance in plants.

Plants under abiotic stress conditions turn on a number of genes and thus levels of several metabolites and proteins increase. Some of these metabolites may be responsible for protection against these stresses. Successful breeding of plants needs to have knowledge about cellular, biochemical and molecular changes in response to stress. In modern molecular strategies, the scientists are looking for the identification and use of molecular markers for enhancement of breeding programs. It seems that genetic engineering would be a fast technique to introduce the beneficial genes toward classical or molecular breeding. Furthermore, it can help classical breeding when there is cross barrier species and distant relatives, or from non-plant sources are considered (Bhatnagar-Mathur et al., 2008).

This review summarizes a definition and introduction of heat stress and its effects on plants and their hormonal and molecular responses. Furthermore, it shows that the nature of each plant and their responses to heat stress in various horticultural and crop plants is special. In this review, it is afforded to explain the interpretation of research data and it is avoided the details of research results.

\section{Heat stress}

Heat stress seems to be one of the main crucial environmental stresses that threaten crops growth and performance, especially by increasing global temperature by $1.5-4.5^{\circ} \mathrm{C}$ by 2050 . The heat stress-induced damage of plants causes the inhibition of photosynthesis, breaking down plant's cell membrane activity, injury and finally death of the cell.

Global climate changes, especially in regional and worldly temperature variations have a significant effect on vegetation and productivity of plants. The temperature has great influence on growth and yield of plants. Various factors cause losses in plant yield upon exposure to high temperature. These factors shorten phases of plant development and perceiving light during the shortened life cycle will be reduced and the processes associated with carbon assimilation (respiration, transpiration and photosynthesis) will be changed. For instance, in order to increase respiration, more carbon fixation is needed for sustainable growth and durability. High temperatures $\left(>35^{\circ} \mathrm{C}\right)$ remarkably reduce the Rubisco activity and consequently reduce photosynthesis. This stress leads to changing the function of membrane primarily due to the membrane fluidity changes. In plants, membrane-related processes, including photosynthesis and respiration are particularly very necessary. Heat stress reduces the efficiency of photosystem II in the chloroplasts that is the most heat-sensitive constituent of photosynthesis processes (Barnabás et al., 2008).

Heat stress is known as temperatures more than a threshold level of a plant for a long period to cause continual damage to growth and development. The complex function of intensity, duration, and the rate of the increase in temperature is known as heat stress. An increase in air temperature may rise the soil temperature. If this situation is accompanied by drought stress due to declining the water content of soil, stress effects may be stronger. High temperature greatly affects the sub-cellular level as well as anatomical structures at the tissue and cellular levels. At the sub-cellular level, main changes include chloroplast shape, swelling the stromal lamellae, the small mass of vacuoles that change the structural organization of thylakoids and form antenna without photosystem II, and therefore reduce the photosynthetic and respiratory activities. These cumulative effects may cause the poor growth and productivity of plant (Lipiec et al., 2013).

The protein denaturation, inactivation of enzymes and increase in the fluidity of membrane lipids and reducing of synthesis and degradation of proteins, and decrease in membrane integrity are the main damages under heat stress. Chronic cellular injury or death may happen at fairly high temperatures after long period or shorter periods at very high temperatures. These injuries may cause to reduce the ion flux and growth of plants, and produce the toxic compounds and reactive oxygen species (ROS). Applications of nutrients as nitrogen, potassium, calcium and magnesium may reduce ROS toxicity through increasing the concentrations of antioxidants agents, including catalase, superoxide dismutase, and peroxidase in the cells of the plant (Lipiec et al., 2013).

Heat stress as an important factor influences on yield and quality of various plants, including horticultural and crop plants, and their final commercial yield will be undergoing the reduction. Among abiotic stresses, heat stress can significantly decrease the tomato yield in the farms. Exposure of tomato to high temperature causes the decrease in fruit set and modifications in the flower morphology, and physiological balances in stress-protective metabolites, including carbohydrates, polyamines and proline are transformed. The major process that is sensitive to non-optimal temperatures and results in fruit set failure is flower developmental processes, and it must be stated that the anthers are more susceptible than the female organs. However, heat stress also affects late pollen development. Lately, the TMS1 gene that encodes a heat shock protein of Hsp40 having DnaJ and PDI domains, was introduced as thermotolerance gene in Arabidopsis that causes pollen tubes continue to grow. However, any mutation in this gene will cause a reduction in seed production. The sensitivity of pollen development to heat stress causes the reduced thermotolerance, because pollen is not able to provide a strong heat stress reaction and, as a result, produces large amounts of heat shock proteins (HSPs) compared to vegetative tissues. These proteins in the forms of low and high molecular weight in numerous plant species are expressed in the early and late stages (Giorno et al., 2009). Therefore, male-sterility and male-fertility in plant lines such as tomato and other crops are an important cue for decreasing yield affected by global warming (Peet et al., 1998). Lily plants show high tolerance to heat stress (temperature between 37 and $42{ }^{\circ} \mathrm{C}$ ) by the improved activities of antioxidant enzymes and glutathione content. In contrary, when symptoms of oxidative stress are visible 
on lily plants at $47^{\circ} \mathrm{C}$, the enhanced electrolyte leakage and malodialdehyde content may be seen due to low ascorbic acid content and prevention of the antioxidant enzyme system, mainly peroxidase and catalase processes (Yin et al., 2008). Furthermore, in crop plants when wheat is exposure to high temperature stress $\left(>30^{\circ} \mathrm{C}\right)$ in reproductive phase this causes adverse influence on producing the viable pollen grains and consequently reducing the seed set (Barnabás et al., 2008). In cotton plants, the tolerance to the high temperature stress directly affects the germination and subsequent growth phases. This means if plant has the tolerance to heat stress during germination of seeds, they will be tolerant plants in late stages. To measure heat tolerance in cotton, the proper and useful method is the measuring of membrane thermal stability as well as many different crops. The major keys of adaptive constituents for high temperature tolerance in cotton include soluble sugars, proline and soluble proteins (Ashraf et al., 1994).

Non-optimal temperatures are the factor of heat stress by all living things. High temperature breaks off cellular homeostasis and greatly delays growth and development leading to death. Globally, severe agricultural injuries are affected by different stresses, including heat, drought or other stresses. It seems that the biosynthesis of HSPs affecting by heat stress transcription factors (HSFs) play a great role in resistance to heat stress and achieving thermotolerance in both plants and other organisms (Kotak et al., 2007). Thermal stress leads to the mis-unfolding of newly biosynthesized proteins and the degradation of existing proteins. That said, the thermal stability of proteins is partly resulted of chaperones. They are specific classes of proteins that can help other proteins to fold suitably after translation process and maintain them in a functional status (Barnabás et al., 2008).

The responses of plants against temperature are different; for example, $35{ }^{\circ} \mathrm{C}$ in tomato and $15{ }^{\circ} \mathrm{C}$ for watermelon cause the lowest weight of the fruits. Therefore, each of these temperatures affects the plants as heat stress (Rivero et al., 2001). When rose flowers are grown in high temperature conditions, the total anthocyanin contents may decrease, and flower's pigment types are adjusted to an increased pelargonidin/ cyanidin ratio (Dela et al., 2003). When plants are in their onset or early growth, plant tissues protect reproductive organs. Stress is fatal; however, the reproductive organs interact indirectly to adverse statuses by mediating the organelles of plants. Therefore, sensitivity to unfavorable conditions in reproductive pathways and the biochemical and molecular processes cannot be described based on responses in vegetative organs (Barnabás et al., 2008). In Table 1, different responses of plant species to the heat stress are summarized. 
Table 1. Different responses of plants to heat stress as tolerance mechanisms

\begin{tabular}{|c|c|c|c|}
\hline Species & $\begin{array}{l}\text { Temperature } \\
\text { range }\left({ }^{\circ} \mathrm{C}\right)\end{array}$ & Plant responses & Reference \\
\hline Tall fescue and Kentucky bluegrass & $35 / 30$ (day/night) & $\begin{array}{l}\mathrm{Ca}^{2+} \text { treatment enhanced antioxidant activities and } \\
\text { decreased membrane lipid peroxidation, without } \\
\text { osmotic adjustment. }\end{array}$ & $\begin{array}{c}\text { Jiang and } \\
\text { Huang (2001) }\end{array}$ \\
\hline Syringa vulgaris & 37 & $\begin{array}{c}\text { The highest } \mathrm{H}_{2} \mathrm{O}_{2} \text { content and the lowest catalase } \\
\text { activity }\end{array}$ & $\begin{array}{l}\text { Jędrzejuk et } \\
\text { al. (2016) }\end{array}$ \\
\hline Dahlia pinnata $\mathrm{Cav}$. & $35 / 30$ (day/night) & $\begin{array}{c}\text { Increase in the malodialdehyde, proline and soluble } \\
\text { protein in paclobutrazole treated Dahlia plants } \\
\text { in high temperature stress, and decrease in their } \\
\text { contents in return to normal temperature. Decrease } \\
\text { in catalase activity at heat stress, and increase } \\
\text { in normal condition. The activity of superoxide } \\
\text { dismutase and peroxidase were kept rising the } \\
\text { whole period. }\end{array}$ & $\begin{array}{l}\text { Zhao et al. } \\
\text { (2018) }\end{array}$ \\
\hline Miniature rose & 36 & $\begin{array}{l}\text { After spraying with salicylic acid, increase in } \\
\text { soluble protein content and superoxide dismutase } \\
\text { and peroxidase activities under high temperature } \\
\text { stress. }\end{array}$ & $\begin{array}{l}\text { Qin et al. } \\
(2018)\end{array}$ \\
\hline Calendula officinalis L. cultivars & $35-42$ & Least membrane stability in sensitive cultivars & $\begin{array}{l}\text { Nazdar et al. } \\
\text { (2019) }\end{array}$ \\
\hline Festuca trachyphylla & 38/33 (day/night) & $\begin{array}{l}\text { Accumulating fatty acids, sterols and proteins in } \\
\text { cell membranes of heat-tolerant germplasm }\end{array}$ & $\begin{array}{l}\text { Wang et al. } \\
\text { (2017) }\end{array}$ \\
\hline $\begin{array}{l}\text { Creeping bentgrass }(\text { Agrostis } \\
\text { stolonifera } \mathrm{L} .) \times \text { colonial bentgrass } \\
\quad(\text { A. capilaris } \mathrm{L} .) \text { hybrids }\end{array}$ & 38/35 (day/night) & $\begin{array}{l}\text { Regulation of leaf senescence in bentgrass exposed } \\
\text { to high temperature conditions with membrane } \\
\text { proteins (light harvesting, photochemical } \\
\text { reactions of photosynthesis and ATP metabolism) } \\
\text { and proteins involved in photo-respiratory and } \\
\text { scavenging of reactive oxygen species. }\end{array}$ & $\begin{array}{l}\text { Jespersen et } \\
\text { al. }(2015)\end{array}$ \\
\hline Paeonia suffruticosa & $35-37$ & $\begin{array}{l}\text { The genes of heat shock protein can enhance stress- } \\
\text { tolerance in peony trees. }\end{array}$ & $\begin{array}{l}\text { Zhang et al. } \\
\text { (2015) }\end{array}$ \\
\hline $\begin{array}{l}\text { Calophyllum longifolium and Ficus } \\
\text { insipida }\end{array}$ & $44-54$ & $\begin{array}{c}\text { Reducing } F_{\mathrm{v}} / F_{\mathrm{m}} \text { in critical temperature, } \mathrm{T}_{50} \text { and } \\
\text { enhancing heat tolerance. }\end{array}$ & $\begin{array}{l}\text { Krause et al. } \\
\quad(2015)\end{array}$ \\
\hline Potentilla fruticosa $\mathrm{L}$. & 42 & $\begin{array}{l}\text { Destroying cell membrane and structure of } \\
\text { chloroplasts, especially the thylakoids, identifying } \\
35 \text { up-regulated and } 23 \text { down-regulated proteins } \\
\text { under high temperature stress }\end{array}$ & $\begin{array}{l}\text { Guo et al. } \\
\text { (2017) }\end{array}$ \\
\hline Tomato (Solanum lycopersicum) & $\begin{array}{l}\text { 32/26 (day/ } \\
\text { night) }\end{array}$ & $\begin{array}{c}\text { Decrease in fruit set, pollen grain and increase } \\
\text { in night respiration in different cultivars and } \\
\text { germination of pollen grains }\end{array}$ & $\begin{array}{l}\text { Sato et al. } \\
\text { (2000) }\end{array}$ \\
\hline
\end{tabular}




\section{Osmotic and oxidative stresses}

Osmotic stress that is also known as osmotic shock is a type of physiological dysfunction, which is occurred by a change in the apoplast solute concentration suddenly. This causes a movement of water across its cell membrane with quick change and drawing water out of the cell with osmosis activity (Lang et al., 2005). Under unfavorable environmental conditions, when the rate of $\mathrm{CO}_{2}$ absorption is reduced, chloroplasts will experience excessive excitation energy and production of reactive oxygen intermediates will increase which will lead to oxidative stress (Hare and Cress, 1997). Even when plants are growing under normal statuses, ROS are constantly biosynthesized as the derivatives of different pathways of metabolism. To prevent the increased ROS (toxic levels), different types of antioxidant defense systems for scavenging ROS are activated. These two stresses are known as secondary stresses. In Table 2, the responses of some plant species to heat stress-induced osmotic and oxidative stresses can be observed.

Accumulation of ABA as one of the most important reactions to osmotic stress is introduced. Osmotic stress signaling includes an ABA-dependent and independent pathway. In addition, osmotic stress increases the generation of ROS and elicitation of different networks of cellular signaling that cause damages to cells physiologically. Certain kinases are activated by osmotic stress signaling, for example the SNF1-related protein kinase (SnRK) in Arabidopsis. The strong effects of ABA are only reported on SnRK2.2, 2.3, and 2.6 but osmotic stress activates nearly all members of SnRK2s. Hiskinases have the role of receptors in osmotic stress (Upadhyaya et al., 2013). Osmotic stress causes the synthesis or catabolism of several growth regulators, including cytokinins, auxin, gibberellins, ethylene, jasmonic acid, brassinosteroids and other factors such as nitrogen and $\mathrm{pH}$. These involve the regulation of physiological processes as signal molecules in signaling networks (Lamaoui et al., 2018).

Environmental stresses such as severe salinity, chilling, freezing and drought stress leads to increase oxidation in plant cells. The use of glycine betaine in the medium, incubated with hydroxyl radicals $\left({ }^{\circ} \mathrm{OH}\right)$ for Arabidopsis roots greatly decreased the flowing $\mathrm{K}^{+}$ions out. Moreover, in tomato, exogenous spraying of glycine betaine remarkably decreased the chilling-induced production of $\mathrm{H}_{2} \mathrm{O}_{2}$. ROS is not directly swept by glycine betaine, but it has a role in reducing the harmful impacts of oxidative conditions, for instance, it activates or stabilizes ROS-scavenging enzymes and suppresses production of ROS and this mechanism is unknown (Chen et al., 2008). One mechanism of heat stress injury is to increase the production of ROS, including hydroxyl radical $\left({ }^{\bullet} \mathrm{OH}\right)$, superoxide radical $\left(\mathrm{O}_{2}{ }^{\bullet}\right)$, singlet oxygen $\left({ }^{1} \mathrm{O}_{2}\right)$ and hydrogen peroxide $\left(\mathrm{H}_{2} \mathrm{O}_{2}\right)$ (Yin et al., 2008; Harsh et al., 2016). When ROS are accumulated can peroxide the membrane lipids, denature the proteins and nucleic acids and disrupt homeostasis. However, plants to alleviate and repair the resultant ROS damage exhibit one series of particular mechanisms. These defensive mechanisms encompass enzymatic systems, including catalase (CAT; EC 1.11.1.6), superoxide dismutase (SOD; EC 1.15.1.1), ascorbate peroxidase (APX; EC1.11.1.11), guaiacol peroxidase (GPOX; EC 1.11.1.7), glutathione reductase (GR; EC 1.8.1.7) and peroxidase (POX; EC 1.11.1.7) and non-enzymatic antioxidants such as anthocyanins, carotenoids, flavonoids and ascorbic acid (Figure 1). The removal of $\mathrm{O}_{2}^{--}$by SOD generates $\mathrm{H}_{2} \mathrm{O}_{2}$, which is removed by peroxidases and CAT (Yin et al., 2008; Harsh et al., 2016). Plants that are resistant to heat stress can change their antioxidant enzymes and antioxidants upon exposure to stress statuses (Yin et al., 2008).

Different enzymes control the metabolism of soluble phenolics. Deamination of L-phenylalanine is the first stage for the synthesis of the phenylpropanoid skeleton in plants (Nag and Kumaria, 2018). Phenylalanine ammonia lyase catalyzes this reaction. This enzyme is known as the main enzyme for the synthesis of phenolic compounds. The activity of phenylalanine ammonia lyase is affected by many factors, whether biotic or abiotic such as light, temperature, plant hormones, inhibitors for RNA and protein biosynthesis, drought and mineral nutrition. It is proclaimed that low and high temperatures cause to produce soluble phenolics and hence increasing phenylalanine ammonia lyase activity (Moura et al., 2017). This enzyme stimulates the transformation of L-Phenyalanine into trans-cinnamic acid (by deamination reaction), which is the main go-between in the synthesis of phenolics (Rivero et al., 2001). 


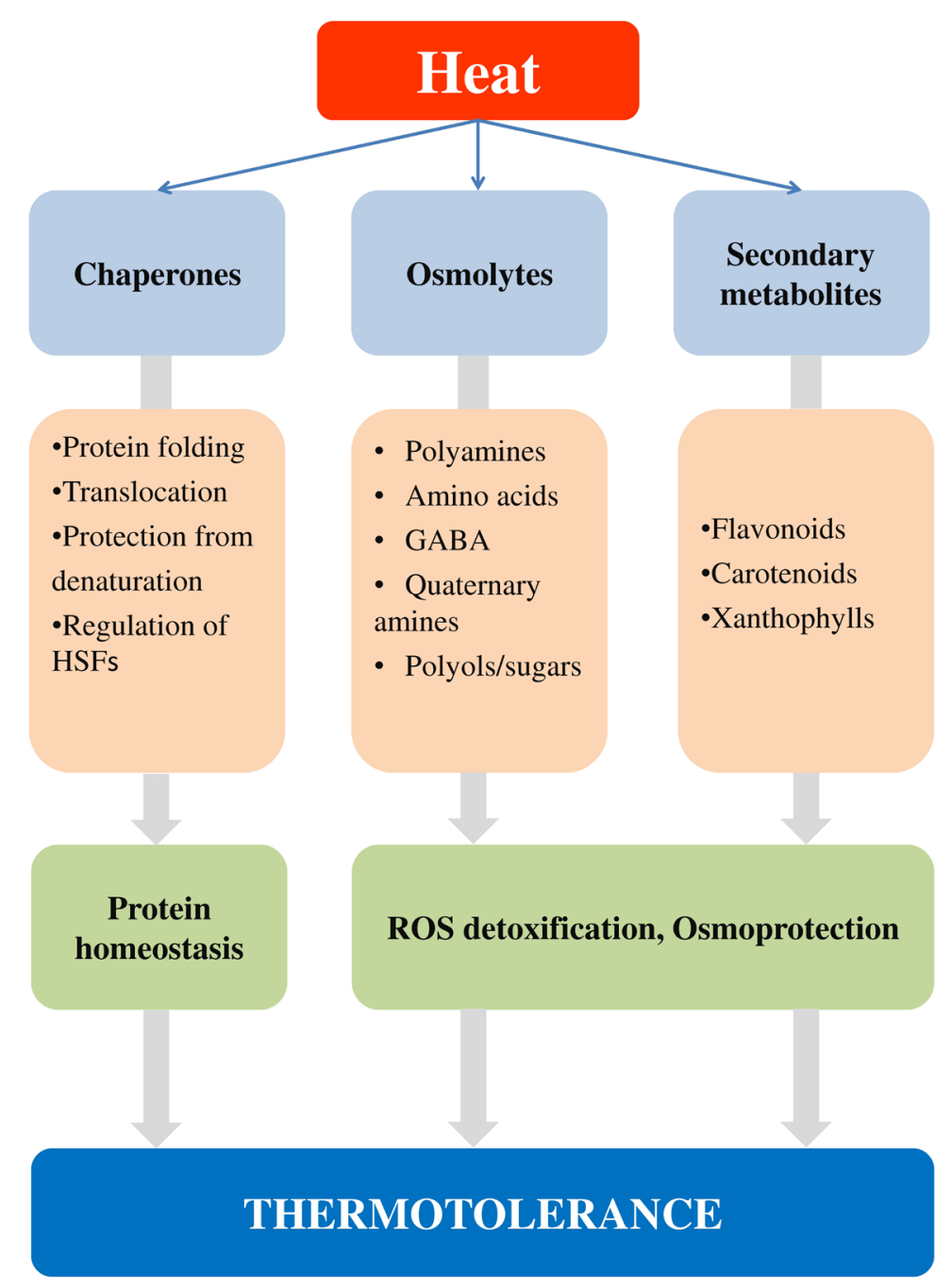

Figure 1. Plants respond to heat stress by three different processes (Bokszczanin et al., 2013)

Phenylalanine ammonia-lyase is known as a response to heat stress and as important lines of cell adaptation against stress in plants. Phenols are oxidized by peroxidase and glycine betaine through polyphenol oxidase. Polyphenol oxidase stimulates the oxidation of $o$-diphenols to $o$-diquinones and hydroxylation of monophenols. These enzymes are triggered to react to various stresses (biotic and abiotic) and especially both enzymes work during the appearance of physiological symptoms that is caused by high temperature conditions in the plants (Rivero et al., 2001). 
Table 2. The responses of some species of ornamental and vegetable plants to heat stress-induced oxidative and osmotic stressesw

\begin{tabular}{|c|c|c|c|}
\hline Species & $\begin{array}{l}\text { Increased processes/ } \\
\text { compounds }\end{array}$ & $\begin{array}{l}\text { Decreased processes/ } \\
\text { compounds }\end{array}$ & References \\
\hline Moth bean (Vigna aconitifolia) & $\begin{array}{l}\text { An increase in the three } \\
\text { antioxidant enzymes (GPOX, } \\
\text { SOD and CAT) along with } \\
\text { osmo-protectants of proline and } \\
\text { sugars. }\end{array}$ & - & Harsh et al. (2016) \\
\hline $\begin{array}{l}\text { Tall fescue (Lolium } \\
\text { arundinaceum) }\end{array}$ & $\begin{array}{c}\text { Electrolyte leakage, expression } \\
\text { of Heat Shock Proteins (HSPs) } \\
\text { gene family (HMW-HSP, } \\
H S P 74.8, L M W-H S P, H S C 70)\end{array}$ & $\begin{array}{c}\text { POD, CAT and SOD activities, } \\
\text { Root activity, Chlorophyll } \\
\text { content, } F v / F m\end{array}$ & Hu et al. (2016) \\
\hline Cucumber (Cucumis sativus) & $\begin{array}{l}\text { Higher accumulations of } \\
\text { osmolytes, i.e., proline, glycine } \\
\text { betaine and soluble sugars both } \\
\text { in leaves and roots }\end{array}$ & $\begin{array}{l}\text { Antioxidant enzymes (SOD, } \\
\text { POD, CAT, APX, GPX and } \\
\text { GTR) activities }\end{array}$ & Balal et al. (2016) \\
\hline $\begin{array}{c}\text { Perennial ryegrass (Lolium } \\
\text { perenne L.) }\end{array}$ & $\begin{array}{l}\text { Ion leakage, } \mathrm{H}_{2} \mathrm{O}_{2} \text { content, } \\
\text { malodialdehyde content (lipid } \\
\text { peroxidation) }\end{array}$ & $F v / F m$ (chlorophyll florescence) & Soliman et al. (2010) \\
\hline Lilium longiflorum & $\begin{array}{l}\text { Relative electrolyte leakage (\%) } \\
\text { and malondialdehyde, } \mathrm{O}_{2}^{--} \text {and } \\
\qquad \mathrm{H}_{2} \mathrm{O}_{2}\end{array}$ & $\begin{array}{c}\text { Ascorbic acid and glutathione } \\
\text { (GSH), activities of SOD, CAT, } \\
\text { APX and GR }\end{array}$ & Yin et al. (2008) \\
\hline Brassica oleracea & $\begin{array}{l}\text { Glutathione content in } 32{ }^{\circ} \mathrm{C} \\
\text { compared to } 20^{\circ} \mathrm{C} \text {; dry weight } \\
\text { loss in } 32{ }^{\circ} \mathrm{C} \text { compared to } 12{ }^{\circ} \mathrm{C}\end{array}$ & $\begin{array}{l}\text { Activities of CAD, SOD, GR } \\
\text { enzymes in } 20^{\circ} \mathrm{C} \text { more than } \\
30^{\circ} \mathrm{C} \text { compared to } 12^{\circ} \mathrm{C} \text {, } \\
\text { Glutathione content in } 20^{\circ} \mathrm{C} \\
\text { compared to } 12^{\circ} \mathrm{C}\end{array}$ & Soengas et al. (2018) \\
\hline
\end{tabular}

\section{Hormonal regulation}

Plant hormones play a key role in different processes of development and have adaptation responses to single or combined environmental signals (Upadhyaya et al., 2013; Balfagón et al., 2019). Among them, ABA, salicylic acid (SA) and ethylene play important role in different plant species during thermal stress signaling. Jasmonates (JAs) and SA, although are widely studied for their roles under biotic stress conditions, also play a role in plant tolerance to abiotic stresses (Balfagón et al., 2019). Auxin and ABA have a role in regulating the water statuses in the plant, but they work in the opposite direction and have the complementary roles in the roots (Upadhyaya et al., 2013).

As for SA, great levels were shown in response to thermal stress in different plant species. It is suggested that SA acts in the same direction of and with opposite direction of phosphatidyl-inositol-4,5-bisphosphate (PtdInsP2)- specific phospholipase C. However, it seems that it do not need to SA like ABA to synthesize HSP in plants under heat stress (Kotak et al., 2007).

ABA is a necessary phytohormone that has an important role to react with adverse statuses for plants such as low temperature stress (Yadav, 2010). It is stated that the $\mathrm{ABA}$ is the key molecule to activate plant reactions to heat, water deficit and salinity. By synthesis of ABA, accumulations of different proteins that have a role in acclimation are induced and this regulates stomatal closure under heat stress and secondary stress i.e. osmotic stress (Balfagón et al., 2019; Lamaoui et al., 2018). For instance, a temporary increase in ABA levels has been reported on reaction to thermal stress in pea plants and during recovery from thermal stress in creeping bentgrass (Kotak et al., 2007). During seed ripening and vegetative stages at the time of cellular dehydration, the endogenous ABA levels will increase in which control many dehydration- 
responsive genes (Upadhyaya et al., 2013). Furthermore, phaseic acid (PA) that is a terpenoid catabolite of ABA acts as a signaling molecule in environmental adaptation and development. The PA selectively changes the expression of ABA-responsive and non-responsive genes (Balfagón et al., 2019).

\section{Molecular regulation}

Environmental stresses, particularly low or high temperature and salt stresses are as main causes of flower losses worldwide and extremely influence growth of plants, and decrease quality of crops or even limit their distribution in geographical regions. The plants acclimatize to the environmental conditions through the molecular networks. The plant begins the planned ways to stop the unsuitable conditions by gene expression (Wang et al., 2014). The reaction of different plants against high temperature may be having some variations and plant exhibit the various types of reactions. The network of heat shock response activates temperature perception mechanisms in Arabidopsis thaliana. This includes a complex signal range of transduction networks and 21 known transcription factors that have the role of activation of heat shock proteins and other genes throughout the high temperature period. We can have the accurate understanding about the heat shock response pathway under study of genome sequence data and then we can achieve the molecular basis of regulatory networks of different types of environmental stresses in Arabidopsis (e.g., cold, salinity, drought) (Swindell et al., 2007).

The stimulation of HSP synthesis is one of the specific aspects of responding to high temperature stress that have been conserved intensively from bacteria to humans. One of the main functions of HSPs includes chaperone functions that prevent alterations or re-folding of deformed (denatured) proteins. It is possible that HSPs involve in the thermotolerance of cereals. High levels of similarities of sequences are observed within the plant kingdom about high molecular weight HSPs (HSP70, HSP90, HSP101). It seems that relevant members or alleles of HSPs may have different specific functions, and this can confirm with a diversity of high molecular weight HSPs family. Moreover, members of the same family of HSP may be activated in various cell compartments (Barnabás et al., 2008; Jacob et al., 2017). This function shows that Hsp20s may lead to the perception of stressful signals and activation of signal transduction processes. In case of high temperature, fluidity of the membrane as a tool for recognizing unfavorable conditions is important and activates signal transduction processes. However, the solubility of the membrane may be changed through non-thermal catalysts or membrane may be damaged, so Hsp20s interactions with membranes can be observed in all of Hsp20 family (Swindell et al., 2007). HSPs were first introduced as heat stress-induced proteins. HSPs may behave as molecular chaperones to control quality of protein.

The reason of the complexity of HSP gene family is that these compounds are necessary for natural maturation and development, in which their roles are difficult to be understood during thermal stress. There are no clear details on the roles of HSP70, HSP90 and HSP60 in preserving plants under high temperature stress yet, although many molecular studies are done (Kotak et al., 2007). The ROS are produced in a common reaction under most of the stressful conditions. Hence, activation of HSF by ROS may confirm this hypothesis that heat shock genes are expressed under most of stresses. However, it is possible that the ROS effects on expression of heat shock genes are unlike other stresses. The ROS lead to oxidative stress; this stress even may be induced by exogenous applications of methyl viologen. This compound causes generating the superoxide anion radical (Swindell et al., 2007).

The strongest inducers that cause the expression of heat shock gene are the osmotic, cold, and salt stresses. These stresses lead to the expression of heat shock genes, which are immense toward other Arabidopsis genes even in an absolute sense, since these agents cause powerful modifications and differential expression in each of $H S F$ and HSP genes. The HSPS and the HSFs are major constituents of the heat shock regulatory system in Arabidopsis thaliana. Furthermore, for a long time, these central components have a role in responding to cold and non-thermal stresses, but what can more strongly been known is the HSP/HSF expression responses have not been recognized yet. In addition, the normal function of these molecules under other stresses is in doubt. We can say that HSPS and HSFs play a common role among cold and heat stresses responses. It must be stated that both of cold and other stresses involve HSFs and HSPS. Different significant patterns of response to stresses in the level of this family of genes have been initiated (Swindell et al., 2007).

Early activation of HsfA2 and Hsp17-CII genes in the diploid mother cells of pollen in tomato prior to the development of microspores and their expression under the long duration of high temperature continues to produce the mature dry pollen. The HsfA2 gene has an important role to activate the preservation mechanisms in the anther of tomato plants when are exposed to high temperature; hence it may have a share in the tomato fruit set under unfavorable temperatures (Giorno et al., 2009). Heat tolerance in plants is a complex trait and several genes control it. For example, in Festuca, high temperature tolerant genotypes respond to stress by promoting the photosynthesis gene expression of photosynthesis, protein biosynthesis and cell preservation in which all are associated with transcription factors. The HSFs are the terminal constituents of signal transduction pathways that mediate in the activation of genes (Barnabás et al., 2008).

Accumulation of high levels of glycine betaine in the reproductive parts of plants could be had the protective effects, for instance, Arabidopsis, maize and tomato can show tolerance to stress affected by glycine betaine. It seems that this accumulation is due to translocation of glycine betaine from leaves to reproductive organs, which can cause tolerance. Furthermore, transgenic plants with the codA transgene have high productivity of flowers and seeds and large fruits under normal statuses. Promotion of 
stress tolerance results in the increased yields of crops and other plants and these needs to investigate in various plants. Some mechanisms may cause plant tolerance to abiotic stress by glycine betaine accumulation are: (1) conservation of photosynthesis process; (2) expression of tolerant genes to different stresses; (3) ROS reduction under stress; and (4) direct regulation of the ion-channel proteins' activities or through preservation of the plasma membrane (Chen et al., 2008).

\section{Conclusions}

Due to the global warming, heat stress can be known as an important global problem for living creatures specially plants and in turn agriculture and finally humanity the worldwide. Because, heat stress decreases the yield of plants and crops as well as vegetative phases. Tolerance to heat stress in plants like other abiotic stresses is quantitative trait and is controlled by many gene loci. Therefore, classical breeding should be integrated with physiological knowledge of stress and genetic engineering to overcome global problems and rapid breeding of plants. Heat stress is accompanied by secondary stresses, including osmotic and oxidative stresses. Tolerant plants respond to these with synthesizing osmolytes and compatible solutes; hormonal networks specially ABA during osmotic stresses and with enzymatic and non-enzymatic antioxidants for scavenging ROS, which are overproduced during shocks that is known as oxidative stress. Therefore, identification of these complex networks in tolerant plants and transforming genes to susceptible ones is quick solution of life perseveration against global warming of earth.

\section{Author Contribution}

S.S.S.M. ${ }^{0000-0001-5455-0970}$ : arranged the sub-titles, wrote the paper and edited it and its integrity; Y.N.S..$^{0000-0002-4601-9757}$ : wrote about physiological effects of heat stress on the plants.

\section{Acknowledgements}

The authors would like to thank the Deputy of Research and Technology in Horticultural Sciences Research Institute (HSRI), Iran and Lebanese University, Lebanon for supporting to report this Review paper.

\section{References}

ASHRAF, M.; SAEED, M.M.; QURESHI, M.J. Tolerance to high temperature in cotton (Gossypium hirsutum L.) at initial growth stages. Environmental and Experimental Botany, v.34, n.3, p.275-283, 1994. DOI: https://doi. org/10.1016/0098-8472(94)90048-5
BALAL, R.M.; SHAHID, M.A.; JAVAID, M.M.; IQBAL, Z.; ANJUM, M.A.; GARCIA-SANCHEZ, F.; MATTSON, N.S. The role of selenium in amelioration of heat-induced oxidative damage in cucumber under high temperature stress. Acta Physiologiae Plantarum, v.38, n.6, p.158, 2016. DOI: https://doi.org/10.1007/s11738-016-2174-y

BALFAGÓN, D.; ZANDALINAS, S.I.; GÓMEZ CADENAS, A. High temperatures change the perspective: Integrating hormonal responses in citrus plants under co occurring abiotic stress conditions. Physiologia Plantarum, v.165, n.2, p.183-197, 2019. DOI: https://doi. org/10.1111/ppl.12815

BARNABÁS, B.; JÄGER, K.; FEHÉR, A. The effect of drought and heat stress on reproductive processes in cereals. Plant, Cell \& Environment, v.31, n.1, p.11-38, 2008. DOI: https://doi.org/10.1111/j.1365-3040.2007.01727.x

BHATNAGAR-MATHUR, P.; VADEZ, V.; SHARMA, K.K. Transgenic approaches for abiotic stress tolerance in plants: retrospect and prospects. Plant Cell Reports, v.27, n.3, p.411-424, 2008. DOI: https://doi.org/10.1007/ s00299-007-0474-9

BOKSZCZANIN, K.L.; FRAGKOSTEFANAKIS, S.; BOSTAN, H.; BOVY, A.; CHATURVEDI, P.; CHIUSANO, M.L.; FIRON, N.; IANNACONE, R.; JEGADEESAN, S.; KLACZYNSKID, K.; LI, H. Perspectives on deciphering mechanisms underlying plant heat stress response and thermotolerance. Frontiers in Plant Science, v.4, p.315, 2013. DOI: https://doi.org/10.3389/fpls.2013.00315

CHEN, T.H.; MURATA, N. Glycinebetaine: an effective protectant against abiotic stress in plants. Trends in Plant Science, v.13, n.9, p.499-505, 2008. DOI: https://doi. org/10.1016/j.tplants.2008.06.007

DELA, G.; OR, E.; OVADIA, R.; NISSIM-LEVI, A.; WEISS, D.; OREN-SHAMIR, M. Changes in anthocyanin concentration and composition in 'Jaguar' rose flowers due to transient high-temperature conditions. Plant Science, v.164, n.3, p.333-340, 2003. DOI: https://doi.org/10.1016/ S0168-9452(02)00417-X

GIORNO, F.; WOLTERS-ARTS, M.; GRILLO, S.; SCHARF, K.D.; VRIEZEN, W.H.; MARIANI, C. Developmental and heat stress-regulated expression of HsfA2 and small heat shock proteins in tomato anthers. Journal of Experimental Botany, v.61, n.2, p.453-462, 2009. DOI: https://doi.org/10.1093/jxb/erp316 
GUO, Y.; WANG, Z.; GUAN, X.; HU, Z.; ZHANG, Z.; ZHENG, J.; LU, Y. Proteomic analysis of Potentilla fruticosa L. leaves by iTRAQ reveals responses to heat stress. PloS One, v.12, n. 8, p.e0182917, 2017. DOI: https://doi.org/10.1371/journal.pone.0182917

HARE, P.D.; CRESS, W.A. Metabolic implications of stress-induced proline accumulation in plants. Plant Growth Regulation, v.21, n. 2, p.79-102, 1997.

HARSH, A.; SHARMA, Y.K.; JOSHI, U.; RAMPURIA, S.; SINGH, G.; KUMAR, S.; SHARMA, R. Effect of short-term heat stress on total sugars, proline and some antioxidant enzymes in moth bean (Vigna aconitifolia). Annals of Agricultural Sciences, v.61, n. 1, p.57-64, 2016. DOI: https://doi.org/10.1016/j.aoas.2016.02.001

HU, L.; ZHANG, Z.; XIANG, Z.; YANG, Z. Exogenous application of citric acid ameliorates the adverse effect of heat stress in tall fescue (Lolium arundinaceum). Frontiers in Plant Science, v.7, p.179, 2016. DOI: https://doi. org/10.3389/fpls.2016.00179

JACOB, P.; HIRT, H.; BENDAHMANE, A. The heatshock protein/chaperone network and multiple stress resistance. Plant Biotechnology Journal, v.15, n.4, p.405-414, 2017. DOI: https://doi.org/10.1111/pbi.12659

JEDRZEJUK, A.; ŁUKASZEWSKA, A.; RABIZAŚWIDER, J.; SKUTNIK, E. Low temperature forcing reduces oxidative stress in lilac flowers. Horticulture, Environment, and Biotechnology, v.57, n.6, p.625-632, 2016. DOI: https://doi.org/10.1007/s13580-016-0141-6

JESPERSEN, D.; XU, C.; HUANG, B. Membrane proteins associated with heat-induced leaf senescence in a coolseason grass species. Crop Science, v.55, n. 2, p.837-850, 2015. DOI: https://doi.org/10.2135/cropsci2014.04.0335

JIANG, Y.; HUANG, B. Effects of calcium on antioxidant activities and water relations associated with heat tolerance in two cool season grasses. Journal of Experimental Botany, v.52, n.355, p.341-349, 2001. DOI: https://doi. org/10.1093/jexbot/52.355.341

KOTAK, S.; LARKINDALE, J.; LEE, U.; VON KOSKULL-DÖRING, P.; VIERLING, E.; SCHARF, K.D. Complexity of the heat stress response in plants. Current Opinion in Plant Biology, v.10, n.3, p.310-316, 2007. DOI: https://doi.org/10.1016/j.pbi.2007.04.011

KRAUSE, G.H.; WINTER, K.; KRAUSE, B.; VIRGO, A. Light-stimulated heat tolerance in leaves of two neotropical tree species, Ficus insipida and Calophyllum longifolium. Functional Plant Biology, v.42, n. 1, p.42-51, 2015. DOI: https://doi.org/10.1071/FP14095
LAMAOUI, M.; JEMO, M.; DATLA, R.; BEKKAOUI, F. Heat and drought stresses in crops and approaches for their mitigation. Frontiers in Chemistry, v.6, p.26, 2018. DOI: https://doi.org/10.3389/fchem.2018.00026

LANG, K.; LANG, P.; BAUER, C.; DURANTON, C.; WIEDER, T.; HUBER, S.; LANG, F. Mechanisms of suicidal erythrocyte death. Cellular Physiology and Biochemistry, v.15, n.5, p.195-202, 2005. DOI: https:// doi.org/10.1159/000086406

LIPIEC, J.; DOUSSAN, C.; NOSALEWICZ, A.; KONDRACKA, K. Effect of drought and heat stresses on plant growth and yield: a review. International Agrophysics, v.27, n.4, p.463-477, 2013. DOI: https://doi. org/10.2478/intag-2013-0017

MOURA, D.S.; BRITO, G.G.; CAMPOS, Â.D.; MORAES, Í.L.; FAGUNDES, P.R.; DEUNER, S. Phenylalanine ammonia-lyase and source-flow-sink related attributes in rice genotypes subjected to high night temperatures. Journal of Agricultural Science, v.9, n.12, p.268-282, 2017. DOI: https://doi.org/10.5539/jas.v9n12pxx

NAG, S.; KUMARIA, S. In silico characterization and transcriptional modulation of phenylalanine ammonia lyase (PAL) by abiotic stresses in the medicinal orchid Vanda coerulea Griff. ex Lindl. Phytochemistry, v.156, p.176-183, 2018. DOI: https://doi.org/10.1016/j. phytochem.2018.09.012

NAZDAR, T.; TEHRANIFAR, A.; NEZAMI, A.; NEMATI, H.; SAMIEI, L. Physiological and anatomical responses of calendula (Calendula officinalis L.) cultivars to heat-stress duration. The Journal of Horticultural Science and Biotechnology, v.94, n.3, p.400-411, 2019.DOI: https:// doi.org/10.1080/14620316.2018.1532324

PEET, M.M.; SATO, S.; GARDNER, R.G. Comparing heat stress effects on male fertile and male sterile tomatoes. Plant, Cell \& Environment, v.21, n.2, p.225-231, 1998. DOI: https://doi.org/10.1046/j.1365-3040.1998.00281.x

QIN, Y.; ZHOU, Z.; LIU, H.; WANG, Y.; LAI, Y.; WANG, Y.; MAO, F.; ZHANG, L.; WANG, H.; ZHANG, G. Effects of exogenous salicylic acid on physiological indexes in miniature rose under high temperature stress. Journal of Southern Agriculture, v.49, n.10, p.2028-2033, 2018.

RIVERO, R.M.; RUIZ, J.M.; GARCIA, P.C.; LOPEZLEFEBRE, L.R.; SÁNCHEZ, E.; ROMERO, L. Resistance to cold and heat stress: accumulation of phenolic compounds in tomato and watermelon plants. Plant Science, v.160, n.2, p.315-321, 2001. DOI: https://doi.org/ S0168-9452(00)00395-2 
SATO, S.; PEET, M.M.; THOMAS, J.F. Physiological factors limit fruit set of tomato (Lycopersicon esculentum Mill.) under chronic, mild heat stress. Plant, Cell \& Environment, v.23, n.7, p.719-726, 2000. DOI: https://doi. org/10.1046/j.1365-3040.2000.00589.x

SHAFIEI MASOULEH, S.S.; JAMAL ALDINE, N.; SASSINE Y.N. 2019. The role of organic solutes in the osmotic adjustment of chilling-stressed plants (vegetable, ornamental and crop plants). Ornamental Horticulture, v.24, n.4, p.434-442, 2019. DOI: https://doi. org/10.1590/2447-536X.v25i4.2073

SOENGAS, P.; RODRÍGUEZ, V.M.; VELASCO, P.; CARTEA, M.E. Effect of temperature stress on antioxidant defenses in Brassica oleracea. ACS Omega, v.3, n.5, p.5237-5243, 2018. DOI: https://doi.org/10.1021/ acsomega. $8 \mathrm{~b} 00242$

SOLIMAN, W.S.; FUJIMORI, M.; TASE, K.; SUGIYAMA, S.I. Oxidative stress and physiological damage under prolonged heat stress in $\mathrm{C}_{3}$ grass Lolium perenne. Grassland Science, v.57, n.2, p.101-106, 2011. DOI: https://doi.org/10.1111/j.1744-697X.2011.00214.X

SWINDELL, W.R.; HUEBNER, M.; WEBER, A.P. Transcriptional profiling of Arabidopsis heat shock proteins and transcription factors reveals extensive overlap between heat and non-heat stress response pathways. BMC Genomics, v.8, n.1, p.125, 2007. DOI: https://doi. org/10.1186/1471-2164-8-125

UPADHYAYA, H.; SAHOO, L.; PANDA, S.K. Molecular physiology of osmotic stress in plants. In: Molecular Stress Physiology of Plants. Springer, India, 2013. p.179192.

VINOCUR, B.; ALTMAN, A. Recent advances in engineering plant tolerance to abiotic stress: achievements and limitations. Current Opinion in Biotechnology, v.16, n.2, p.123-132, 2005. DOI: https://doi.org/10.1016/j. copbio.2005.02.001
WANG, J.; JULIANI, H.R.; JESPERSEN, D.; HUANG, B. Differential profiles of membrane proteins, fatty acids, and sterols associated with genetic variations in heat tolerance for a perennial grass species, hard fescue (Festuca Trachyphylla). Environmental and Experimental Botany, v.140, p.65-75, 2017. DOI: https:// doi.org/10.1016/j.envexpbot.2017.05.014

WANG, J.; WANG, Q.; YANG, Y.; LIU, X.; GU, J.; LI, W.; MA, S.; LU, Y. De novo assembly and characterization of stress transcriptome and regulatory networks under temperature, salt and hormone stresses in Lilium lancifolium. Molecular Biology Reports, v.41, n.12, p.8231-8245, 2014. DOI: https://doi.org/10.1007/s11033014-3725-1

YADAV, S.K. Cold stress tolerance mechanisms in plants. A review. Agronomy for Sustainable Development, v.30, p.515-527, 2010. DOI: https://doi.org/10.1051/ agro/2009050

YIN, H.; CHEN, Q.; YI, M. Effects of short-term heat stress on oxidative damage and responses of antioxidant system in Lilium longiflorum. Plant Growth Regulation, v.54, n.1, p.45-54, 2008. DOI: https://doi.org/10.1007/ s10725-007-9227-6

ZHANG, Y.Z.; CHENG, Y.W.; YA, H.Y.; HAN, J.M.; ZHENG, L. Identification of heat shock proteins via transcriptome profiling of tree peony leaf exposed to high temperature. Genetics and Molecular Research, v.14, n.3, p.8431-8442, 2015. DOI: https://doi.org/10.4238/2015. July. 28.10

ZHAO, C.; GUAN, H.; YUAN, X.; LI, X.; GAO, L.; SHEN, C.; TAN, J. Effects of paclobutrazol on physiological parameters of dahlia under heat stress. Agricultural Biotechnology, v.7, n.5, p.67-70, 2018. 